\title{
Metabotropic Glutamate Receptor 5
}

National Cancer Institute

\section{Source}

National Cancer Institute. Metabotropic Glutamate Receptor 5. NCI Thesaurus. Code C26241.

Metabotropic glutamate receptor 5 (1212 aa, $132 \mathrm{kDa}$ ) is encoded by the human GRM5 gene. This protein plays a role in both glutamate binding and downstream signal transduction. 